\title{
Effect of intercropping on the parasitoids, Encarsia spp. and Trichogramma spp. in cotton fields, India
}

\author{
Suman Devi, , Pala Ram and Krishna Rolania
}

\begin{abstract}
Intercropping in cotton is of great significance, which helps to reduce the population of insect pests by attracting natural enemies to the field and helping to get stabilized yield and high profit advantage. The study was conducted with 4 intercrops, viz., sesame, Sesamum indicum L.; pigeonpea, Cajanus cajan L.; pearl millet, Pennisetum glaucum L.; and sorghum, Sorghum bicolor L. in an experimental area during 2016 and 2017 autumn season. The objective was to study the population of parasitoids influenced by the intercrops in cotton. This is a triangular relationship between the host, parasitoids, and environment. As Encarsia spp. (Hymenoptera: Aphelinidae) and Trichogramma spp. (Hymenoptera: Trichogrammatidae) are the main parasitoids of insect pests of cotton, thus the study was undertaken on these parasitoids. The results revealed that the highest parasitization of whitefly, Bemisia tabaci (Gennadius) pupae by Encarsia spp., was recorded in cotton-pigeonpea 1:1 (33.22\%), which was at par with cotton-pigeonpea 2:1 (32.16\%), whereas the second highest one was in cotton-sesame 1:1 (27.33\%), while the lowest parasitization was recorded in the control (16.16\%). On the activity of Trichogramma spp., the significant highest percent was recorded in cotton-sesame 1:1 (10.93\%), while no activity was recorded in cotton-pigeonpea, cotton-sorghum, cotton-pearl millet, and control treatments.
\end{abstract}

Keywords: Intercropping, Cotton, Habitat manipulation, Conservation, Parasitoids, India

\section{Background}

Cotton, Gossypium arboreum L., is known as the queen of fibers, and it is the most important commercial crop for raw material needs of the textile industry. Although, it is attacked by several insect pests causing drastic reductions in quality and quantity (Dhaliwal et al. 2006). To mitigate the losses caused by insect pests, farmers still rely on chemical pesticides as they considerably control the pests, but injudicious use of pesticides has resulted in harm to non-targeted beneficial organisms and the environment (Patil et al. 2017). So the use of insecticides for the control of the pests has been highly criticized, and therefore, it is forced to switch from insecticides to ecofriendly approaches such as intercropping and cultural

\footnotetext{
* Correspondence: narwal_suman@yahoo.in

Department of Entomology, Chaudhary Charan Singh Haryana Agricultural University, CCS HAU, Hisar, Haryana 125004, India
}

control. Intercropping is the agronomic practice of growing two or more crops in the same field at the same time (Andrews and Kassam 1976; Theunissen 1997). Crop diversification or intercrops provide pollen, nectar, and honeydew as alternate non-prey foods to the adult stages of the parasitoids in adverse conditions (Landis et al. 2000; Gurr et al. 2003; Sharma et al. 2009; Lessando 2019). Parasitic wasp belonging to genus Encarsia (Hymenoptera: Aphelinidae) has a number of species and well known parasitoid of the silver leaf whitefly, Bemisia tabaci (Gennadius) (Hemiptera: Aleyrodidae), with a wide distribution worldwide (Qiu et al. 2003). These are recognized as one of the most important natural enemies of $B$. tabaci having generated a lot of interest in countries, where $B$. tabaci is a problem. They oviposit under the host and develop in a vital capsule within the host (Antony et al. 2003). Adult parasitoids preferentially oviposit within the

\section{Springer Open}

(0) The Author(s). 2020 Open Access This article is licensed under a Creative Commons Attribution 4.0 International License, which permits use, sharing, adaptation, distribution and reproduction in any medium or format, as long as you give appropriate credit to the original author(s) and the source, provide a link to the Creative Commons licence, and indicate if changes were made. The images or other third party material in this article are included in the article's Creative Commons licence, unless indicated otherwise in a credit line to the material. If material is not included in the article's Creative Commons licence and your intended use is not permitted by statutory regulation or exceeds the permitted use, you will need to obtain permission directly from the copyright holder. To view a copy of this licence, visit http://creativecommons.org/licenses/by/4.0/. 
third and the fourth instar nymph of whitefly, and the greatest rate of development occurs when the third instar whitefly nymphs are parasitized (Gerling and Fried 2000). The genus Trichogramma Westwood (Hymenoptera: Trichogrammatidae) has the largest number of species in the family Trichogrammatidae. They are used worldwide and having the ability to parasitize eggs of many economic lepidopterous pests of cultivated plants (Hassan 1993; Smith 1996; Mills 2010). They have been used to treat millions of hectares of agricultural crops and forests against diverse insect pests ( $\mathrm{Li}$ 1994), and it is reported that increasing the diversity within crops provided a greater number of opportunities for Trichogramma to survive in agricultural systems (Ram et al. 2002). Thus, there is a need to document the effect of habitat manipulation using intercrops along with main crop in sustaining and supporting the parasitoids and subsequently diminish the outbreaks of insect pests.

The present investigation was undertaken to study the effect of intercropping on the abundance of parasitoids, Encarsia spp. and Trichogramma spp. in cotton crop.

\section{Material and methods}

The studies were conducted at the experimental area of the Department of Entomology, CCS Haryana Agricultural University $\left(29.14^{\circ}\right.$ north latitude and $75.70^{\circ}$ east longitude with an altitude of $215 \mathrm{~m}$ above mean sea level), Hisar, Haryana, India, during 2016 and 2017.

\section{Treatments}

Cotton variety, HD-432, was sown on 14 May and 11 May during 2016 and 2017, respectively. Four intercrops were taken, i.e., sesame (Sesamum indicum L.; variety: HT-1), pigeonpea (Cajanus cajan L.; variety: Paras), pearl millet (Pennisetum glaucum L.; variety: HHB-67i), and sorghum (Sorghum bicolor L.; variety: HC-171). All intercrops were sown in the second fortnight of July in both the years. The plot size was of $22.65 \mathrm{~m}^{2}$ composed of 6 rows of cotton of $4.8 \mathrm{~m}$ length, with a spacing of $67.5 \mathrm{~cm}$ between the rows and $30 \mathrm{~cm}$ between the plants. There were 9 treatments (Table 1). The treatments replicated thrice in a randomized block design (Fig. 1, layout plan of experiment). All recommended cultural practices were applied until harvest, without applying chemical control in the experimental areas.

\section{Encarsia spp.}

Parasitization of whitefly pupa by Encarsia spp. was recorded in all the treatments which started from the 1st week of July to the end of September at 10 days intervals. Thirty leaves from 10 plants (i.e., 3 leaves per plant) in each plot were plucked randomly to record parasitization of whitefly pupae. These leaves were collected in polythene bags, transferred to the laboratory, and examined under the binocular microscope. Black pupae of whitefly were considered parasitized. Parasitized and healthy pupae of whitefly were counted on the leaves. Percent parasitization was calculated as the parasitized (black) pupae divided by the total number of pupae $\times 100$.

\section{Trichogramma spp.}

The activity of Trichogramma spp. was studied by tagging the eggs of rice moth, Corcyra cephalonica (Stainton) (Lepidoptera: Pyralidae) in the field of cotton in all the treatments starting from the 3rd week of July at 15 days intervals. For this study, about 30 fresh and sterilized eggs of rice moth were glued on the paper strip $(5.08 \times 2.54 \mathrm{~cm})$.

Table 1 Effect of intercropping on parasitization of whitefly pupae by Encarsia spp. in cotton (pooled of 2016 and 2017)

\begin{tabular}{|c|c|c|c|c|c|c|c|}
\hline \multirow[t]{2}{*}{ Treatments } & \multicolumn{7}{|c|}{ Percent parasitization of whitefly pupae per 30 leaves } \\
\hline & 5 July & 16 July & 2 August & 17 August & 2 Sept & 19 Sept & Mean \\
\hline Cotton + sesame 1:1 & $43.33(41.15)^{* *}$ & $45.00(42.11)$ & $27.33(31.50)$ & $23.33(28.85)$ & $15.33(22.99)$ & $9.66(18.07)$ & $27.33^{*}(30.79)^{b}$ \\
\hline Cotton + sesame $2: 1$ & $26.33(30.85)$ & $44.00(41.53)$ & $26.00(30.63)$ & $19.33(26.06)$ & $19.33(26.06)$ & $9.33(17.74)$ & $24.05(28.82)^{b}$ \\
\hline Cotton + sesame $3: 1$ & $22.33(28.18)$ & $39.00(38.62)$ & $23.00(28.63)$ & $17.66(24.83)$ & $13.00(21.08)$ & $8.00(16.35)$ & $20.50(26.30)^{c}$ \\
\hline Cotton + pigeonpea 1:1 & $43.33(41.15)$ & $50.66(45.36)$ & $35.33(36.45)$ & $30.33(33.39)$ & $30.33(33.39)$ & $9.33(17.74)$ & $33.22(34.59)^{a}$ \\
\hline Cotton + pigeonpea 2:1 & $34.66(36.04)$ & $46.66(43.06)$ & $34.00(35.64)$ & $23.33(28.85)$ & $44.66(41.91)$ & $9.66(18.08)$ & $32.16(33.94)^{a}$ \\
\hline Cotton + pigeonpea 3:1 & $32.33(34.63)$ & $45.00(42.11)$ & $26.33(30.85)$ & $26.33(30.85)$ & $25.00(29.97)$ & $8.66(17.10)$ & $27.28(30.82)^{b}$ \\
\hline $\begin{array}{l}\text { Cotton + pearl millet } \\
\text { (border crop) }\end{array}$ & $15.33(23.03)$ & $36.00(36.85)$ & $19.33(26.06)$ & $14.33(22.21)$ & $14.00(21.93)$ & $9.33(17.77)$ & $18.05(24.65)^{c}$ \\
\hline $\begin{array}{l}\text { Cotton + sorghum } \\
\text { (border crop) }\end{array}$ & $19.00(25.81)$ & 30.33 (33.39) & $18.33(25.30)$ & $19.33(26.06)$ & $12.33(20.53)$ & $7.00(15.17)$ & $17.72(24.42)^{c}$ \\
\hline Sole cotton (control) & $22.66(28.41)$ & $33.66(35.44)$ & $13.66(21.63)$ & $14.66(22.47)$ & $7.66(16.01)$ & $4.66(12.35)$ & $16.16(22.76)^{d}$ \\
\hline $\begin{array}{l}\text { Standard error of mean } \\
(\mathrm{SE} \pm \mathrm{m})\end{array}$ & $(0.59)$ & $(1.02)$ & $(0.80)$ & $(0.74)$ & $(0.86)$ & $(0.90)$ & $(1.30)$ \\
\hline $\begin{array}{l}\text { Critical difference } \\
\text { (CD at } 5 \%)\end{array}$ & $(1.80)$ & $(3.11)$ & $(2.42)$ & $(2.25)$ & $(2.61)$ & $(2.72)$ & $(3.72)$ \\
\hline
\end{tabular}

*Means in column with the same letter are not significantly different at 0.05 levels (DMRT test)

**Figures in parentheses are angular transformed values 


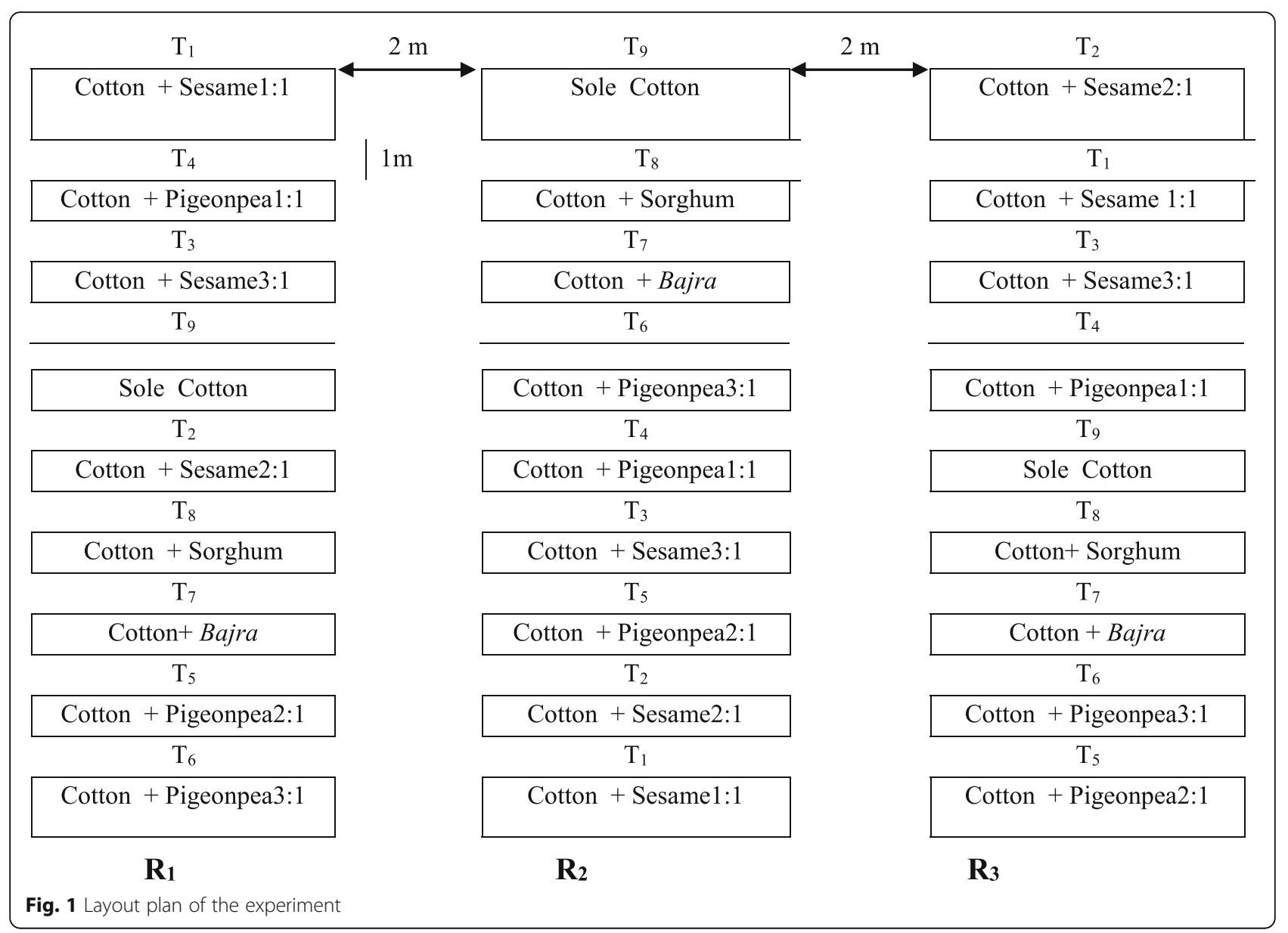

In each plot, 5 such strips of rice moth eggs were tagged on 5 randomly selected plants. These strips were collected from the field after 2 days of exposure in the field. The strips were kept in the laboratory under observation, and parasitization of eggs was recorded using a binocular microscope by observing the presence of black eggs. Percent parasitization was calculated by the parasitized (black) eggs divided by the total number of eggs $\times 100$.

\section{Statistical analysis}

Data were analyzed, using the analysis of variance (ANOVA), and means were separated, using DMRT (Duncan's multiple range test) with SPSS 19 software.

\section{Results and discussion \\ Encarsia spp.}

The results of intercropping on the parasitization of whitefly pupae by Encarsia spp. recorded were significantly higher $(F=10.88, d f=53, p<0.05)$ than sole cotton crop (Table 1). Among intercropping treatments, the highest parasitization by Encarsia spp. was recorded in cottonpigeonpea 1:1 (33.21\%), which was statistically at par with cotton-pigeonpea 2:1 (32.16\%), followed by cotton- pigeonpea 3:1 (27.27\%), cotton-sesame 1:1 (27.33\%), and cotton-sesame 2:1 (24.05\%). The lowest parasitization was recorded in cotton pearl millet (18.05\%) and sorghum $(17.77 \%)$ as border crops. Similar findings were recorded by Kavitha et al. (2003) and Kedar et al. (2014) that cotton intercropped with legumes increased the activity of Encarsia in the field. Zhang et al. (2020) also studied that diversity within the main crop increased the parasitization of whitefly pupae by parasitoids as diversification provided pollen, nectar, and honeydew as alternate non-prey foods to the adult stages of the parasitoids (Deguine 2007; Mote et al. 2001; Poveda et al. 2008).

\section{Trichogramma spp.}

The results of intercropping on the parasitization by Trichogramma spp. was studied under the field conditions. The eggs of rice moth, Corcyra cephalonica, were tagged in each plot, and parasitization were recorded after 2 days of exposure in the field. The significantly highest $(F=44, d f=$ 98) parasitization was recorded in cotton + sesame 1:1 (10.93\%), followed by cotton + sesame 2:1 (6.13\%), and cotton + sesame 3:1 (3.73\%), whereas no parasitization was recorded in the rest of the treatments (Table 2). The present 
Table 2 Effect of intercropping on the activity of Trichogramma spp. (pooled of 2016 and 2017)

\begin{tabular}{lllllll}
\hline Treatments & \multicolumn{4}{l}{ Percent parasitization of eggs of rice moth by Trichogramma spp. } \\
\cline { 2 - 6 } & 15 July & 30 July & 15 August & 30 August & 15 Sept & Mean \\
\hline Cotton + sesame 1:1 & $11.33(19.61)^{* *}$ & $17.00(24.33)$ & $10.33(18.72)$ & $10.00(18.37)$ & $6.00(14.04)$ & $10.93(19.06)^{* a}$ \\
Cotton + sesame 2:1 & $6.67(14.92)$ & $9.67(18.07)$ & $4.67(12.45)$ & $6.67(14.92)$ & $3.00(9.88)$ & $6.13(14.09)^{b}$ \\
Cotton + sesame 3:1 & $3.00(9.87)$ & $6.33(14.50)$ & $5.33(13.33)$ & $2.67(9.26)$ & $1.33(5.42)$ & $3.73(10.78)^{c}$ \\
Cotton + pigeonpea 1:1 & $0(1.15)$ & $0(1.15)$ & $0(1.15)$ & $0(1.15)$ & $0(1.15)$ & $0(1.15)$ \\
Cotton + pigeonpea 2:1 & $0(1.15)$ & $0(1.15)$ & $0(1.15)$ & $0(1.15)$ & $0(1.15)$ & $0(1.15)$ \\
Cotton + pigeonpea 3:1 & $0(1.15)$ & $0(1.15)$ & $0(1.15)$ & $0(1.15)$ & $0(1.15)$ & $0(1.15)$ \\
Cotton + pearl millet (border crop) & $0(1.15)$ & $0(1.15)$ & $0(1.15)$ & $0(1.15)$ & $0(1.15)$ & $0(1.15)$ \\
Cotton + sorghum (border crop) & $0(1.15)$ & $0(1.15)$ & $0(1.15)$ & $0(1.15)$ & $0(1.15)$ & $0(1.15)$ \\
Sole cotton (control) & $0(1.15)$ & $0(1.15)$ & $0(1.15)$ & $0(1.15)$ & $0(1.15)$ & $0(1.15)$ \\
Standard error of mean (SE \pm m) & $(0.57)$ & $(0.49)$ & $(0.29)$ & $(0.58)$ & $(1.11)$ & $(3.36)$
\end{tabular}

*Means in column with the same letter are not significantly different at 0.05 levels (DMRT test)

**Figures in parentheses are angular transformed values

study was in accordance with Ram et al. (2002) who reported that the parasitization of the eggs of til hawk moth, Acherontia styx L. (Lepidoptera: Sphingidae), on sesame crop in large numbers and the eggs of $A$. styx were quite big from which more than 20 Trichogramma adults emerged from a single egg. Similarly, Lester and Furr (1972) recorded the parasitization by Trichogramma in sesame crop. Amala and Shivalingaswamy (2018) and Zhu et al. (2015) also recorded a higher activity of Trichogramma in the diversified system. However, the present findings showed that there was no parasitization by Trichogramma in cotton-sorghum and pearl millet treatments, but Scholz and Parker (2004); Hegde et al. (2003); Romeis et al. (2003); and Díaz et al. (2012) recorded the activity of Trichogramma in sorghum crop. The difference could be due to the climatic condition and crop cultivation practices of the region where the experiment was conducted.

\section{Conclusion}

It is concluded from the studies that the activity of Encarsia spp. and Trichogramma spp. were found to be greater in cotton intercropped with pigeonpea or sesame. Provisioning the parasitoids with intercrops/border crops as pigeonpea and sesame will help in sustaining their population in the agricultural habitats to enhance biological control of insect pests. Habitat manipulation strategies using intercrops should be integrated with the farm landscape in a spatial and temporal way to benefit parasitoids and predators for natural biological control of insect pests.

\section{Abbreviation}

DMRT: Duncan's multiple range test

\section{Acknowledgments}

The authors are highly grateful to the Department of Entomology, Chaudhary Charan Singh Haryana Agricultural University, Hisar, India, for providing the facilities required to conduct this experiment.

\section{Authors' contributions}

Dr. Pala Ram was my PhD advisor and helped me in selecting the objective of my research and thesis writing. Dr. Krishna Rolania was my PhD co-advisor and she helped me in the interpretation and analysis of my research data. The author(s) read and approved the final manuscript.

Funding

Not applicable

\section{Availability of data and materials \\ Not applicable}

Ethics approval and consent to participate

Not applicable

\section{Consent for publication}

Not applicable

\section{Competing interests}

The authors declare that they have no competing interests.

Received: 1 April 2020 Accepted: 27 May 2020

Published online: 09 June 2020

\section{References}

Amala U, Shivalingaswamy TM (2018) Effect of intercrops and border crops on the diversity of parasitoids and predators in agro-ecosystem. Egypt J Biol Pest Control 28:11

Andrews DJ, Kassam AH (1976) The importance of multiple cropping in increasing world food supplies. Pages 1-10 in multiple cropping (Papendick RI, Sanchez PA. and Triplett G B. eds.). American Society of Agronomy Special Publication 27

Antony B, Palaniswami MS, Henneberry TJ (2003) Encarsia transvena (Hymenoptera: Aphelinidae) development on different Bemisia tabaci Gennadius (Homoptera: Aleyrodidae) instars. Environ Entomol 32(3):584-591

Deguine JP (2007) Agro ecology and ecological engineering for pest management-cotton protection as a case study. http://wrc.confex.com/ wcrc/2007/techprogram/p1284HTM.

Dhaliwal GS, Singh R, Chhillar BS (2006) Essentials of agricultural entomology. Kalyani Publishers, Ludhiana, 451

Díaz MF, Ramírez A, Poveda K (2012) Efficiency of different egg parasitoids and increased floral diversity for the biological control of noctuid pests. Biological Control 60:182-191

Gerling D, Fried R (2000) Biological studies with Eretomocerus mundus (Hymenoptera: Aphelinidae). J Econ Entomol 87:117-123

Gurr GM, Wratten SD, Luna JM (2003) Multi-function agricultural biodiversity: pest management and other benefits. Basic Appl Ecol 4:107-116 
Hassan SA (1993) The mass rearing and utilization of Trichogramma to control lepidopterous pests: achievements and outlook. Pestic Sci 37(4):387-391

Hegde M, Kulkarni KA, Lingappa S (2003) Impact of intercrops on conservation of Chrysoperla carnea (Stephens) and other natural enemies in cotton ecosystems. Indian J Plant Prot 31:98-104

Kavitha G, Ram P, Saini RK (2003) Impact of strip crops on the population of arthropod predators and insect pests in cotton. J of Biologic Control 17:17-21

Kedar SC, Saini RK, Malliaiah K, Sharma SS (2014) Record of natural enemies of whitefly, Bemisia tabaci (Gennadius) (Hemiptera: Aleyrodidae) in some cultivated crops in Haryana. J of Biopest 7:57-59

Landis DA, Wratten SD, Gurr GM (2000) Habitat management to conserve natural enemies of arthropod pests in agriculture. Annu Rev Entomol 45:175-201

Lessando MG (2019) Engineering natural enemy shelters to enhance conservation biological control in field crops. Bio Control 130(1):155-163

Lester ML, Furr RE (1972) Heliothis populations in cotton sesame inter-plantings. J Econ Entomol 65:1524-1525

Li LY (1994) Worldwide use of Trichogramma for biological control on different crops: a survey. In: Wajnberg E, Hassan SA (eds) Biological Control with Egg Parasitoids. CAB International, Wallingford, pp 37-53

Mills N (2010) Egg parasitoids in biological control and integrated pest management. In: Cônsoli FL, JRP P, Zucchi RA (eds) Egg parasitoids in agro ecosystems with emphasis on Trichogramma. Springer, Dordrecht, pp 389-412

Mote UN, Patil MB, Tambe AB (2001) Role of intercropping in population dynamic of major pests cotton ecosystem. Ann of Plant Prot Sci 9:36-40

Patil SB, Goyal A, Satish S, Chitgupekar KS, Mustapha B (2017) Sustainable management of chickpea pod borer. Agron Sustain Dev 37:20-37

Poveda K, Gomez MI, Martinez E (2008) Diversification practices: their effects on pest regulations and production. Rev Col Entomol 34(2):131-144

Qiu B, Ren S, Xiao Y, Mandour NS (2003) Effectiveness of Eretomocerus sp. and Aschersonia aleyrodis in controlling Bemisia tabaci population. Bull Entomol Res 14(14):2251-2254

Ram P, Sharma SS, Saini RK (2002) Role of egg parasitism by Trichogramma chilonis Ishii to control Helicoverpa armigera in cotton-sesame intercropping. J Cotton Res Dev 16(1):107-109

Romeis J, Shanover TG, Zebitz CPW (2003) Trichogramma egg parasitism of Helicoverpa armigera on pigeonpea and sorghum in southern India. Entomologia Experimentalis et Applicata 19:69-81

Scholz B, Parker N (2004) The nursery value of sorghum intercropped with cotton-The effects of Heliothis egg parasitism and predator abundance. 11th Australian cotton conference proceedings 1-10. Theme: Quality cotton a living industry not just another yarn held on 10-12 August, 2004. Broad beach, Queensland. Australian Cotton Growers Research Association

Sharma OP, Lavekar RC, Murthy KS, Puri SN (2009) Habitat diversity and predatory insects in cotton IPM: case study of Maharashtra cotton eco-system. IPM World Textbook. University of Minnesota, USA, pp 1-5

Smith SM (1996) Biological control with Trichogramma: advances, success, and potential of their use. Annu Rev Entomol 41:375-406

Theunissen J (1997) Intercropping in field vegetables as an approach to sustainable horticulture. Outlook Agric 26(2):95-99

Zhang X, Ferrante M, Wan F, Yang N, Lovie GL (2020) The parasitoid Eretomocerus hayati is compatible with barrier cropping to decrease whitefly (Bemisia tabaci MED) densities on cotton in China. Insects 11:57-69

Zhu P, Wang G, Zheng X, Tian J, Lu Z, Heong KL, Xu Z, Chen G, Yang Y, Gurr GM (2015) Selective enhancement of parasitoids of rice Lepidoptera pests by sesame (Sesamum indicum) flowers. Bio Control 60:157-167

\section{Publisher's Note}

Springer Nature remains neutral with regard to jurisdictional claims in published maps and institutional affiliations.

\section{Submit your manuscript to a SpringerOpen ${ }^{\odot}$ journal and benefit from:}

- Convenient online submission

- Rigorous peer review

- Open access: articles freely available online

High visibility within the field

- Retaining the copyright to your article

Submit your next manuscript at $\boldsymbol{\nabla}$ springeropen.com 